И.Г. Цыганков, Н.И. Дзюбенко, М.Ю. Цыганкова, Т.С. Шанинов // «Достижения и перспективы селекции, семеноводства с.-х. культур и богарного земледелия»: сб. пленарных докл. Межд. научно-практ. конф., посв. 100-летию создания Красноводопадской СХОС // - Шымкент: «Жебе-дизайн», 2011. - С. 186-199.

12. Савченко И.В. Селекция и генетические ресурсы / И.В. Савченко // Сб. научных материалов Шатиловских чтений, посв. 115-летию Шатиловской СХОС - Орел: РАСХН, ВНИИЗБК, Шатиловская СХОС. 2011. - С. 3-8.

13. Абугалиева А.И., Туруспеков Е.К., Абугалиева С.И. и др. Генетические ресурсы культурного и дикого ячменя // Монография. - Алматы, «Асыл кітап», 2011. $336 \mathrm{c}$.

14. Липшин А.Г. Сибирский генофонд ячменя и его использование для селекции в Восточной Сибири // Автореф. на соискание ... уч. степени канд. с.-х. наук (06.01.05). Красноярск: КрасГАУ, 2016. - 19 с.

15. Аниськов Н.И., Поползухин П.В., Николаев П.Н., Сафонова И.В. Использование генофонда Всероссийского института растениеводства для создания сортов ярового ячменя в Западной Сибири // Вестник КрасГАУ. 2016. № 1. - С. 123-129.

16. Turuspekov Y., Sariev B., Chudinov V., Sereda G., Tokhetova L., Ortaev A., Tsygankov V., Doszhanov M., Volis S., Abugalieva S. Genotype x environment interaction patterns for grain yield of spring barley in different regions of Kazakhstan // Russian Journal of Genetics - Vol. 49. No. 2. 2013. - P. 196-205.

17. Зотиков В.И. Роль генетических ресурсов в повышении продуктивности и экологической устойчивости растениеводства // «Зернобобовые и крупяные культуры» № 2 (22) 2017 г. - С. 4-8.

18. Ситпаева Г.Т. Организация банка семян диких сородичей культурных растений Казахстана / Г.Т. Ситпаева, Т.Ш. Мурзатаева, К.Х. Махмудова // Материалы Межд. конф. по биологии и биотехнологии растений: Алматы: ИББР, 2014. - С. 251.

19. Привалов Ф.И., Гриб С.И., Матыс И.С. Государственная программа «Генофонд» - основа формирования национального банка генетических ресурсов растений Беларуси / Ф.И. Привалов, С.И. Гриб, И.С. Матыс // Мат. Межд. научно-практ. конф. (14-15 апреля 2016 г., г. Жодино). Минск: ИВЦ Минфина, 2016. - С. 175-178.

DOI 10.18699/GPB2020-121

\title{
Качество зерна твердой пшеницы в условиях Карабалыкской СХОС: глютен-индекс
}

Чудинов В.А. ${ }^{1}$, Абугалиева А.И. ${ }^{2}$, д.б.н., проф.

${ }^{1}$ ТОО «Карабалькккая СХОС», Костанай, Казахстан;

${ }^{2}$ ТОО «КазНИИЗиР», Алмалььбак, Казахстан.

Качество яровой твердой пшениџы оценено по стандартам ГОСТ и ИСО (Глютен Индекс) ранее не использованных в классификации отечественных сортов. В селекционных питомниках выделены образцы с высоким значением глютен индекса. По всем показателям качества выделены геноmuпьл: Г2441, Г2246, Шарифа, Асангали; а также ряд образиов с высоким значением глютен-индекса Г2510 (89); Г2242 (88); Г1764 (86); Алтьлн Дала (89), на который селекиия ранее не велась. 
Ключевые слова: Твердая пшеница, качество клейковины, глютен-индекс.

\section{Quality of durum wheat in Karabalyk station: gluten index}

Chudinov V.A., Karabalykskaya Agricultural Station LLP, Kostanay, Kazakhstan Abugalieva A.I., Doctor of Biological Sciences, prof., Kazakh Research Institute of Agricultural and Plant Growing LLP, Almalybak, Kazakhstan.

The quality of spring durum wheat was evaluated according to state and ISO (Gluten Index) standards not previously used in the classification of domestic varieties. In breeding nurseries, samples with a high gluten index value were isolated. Genotypes were identified for all quality indicators: $\Gamma 2441, \Gamma 2246$, Sharifa, Asangali; as well as a number of samples with a high gluten index G2510 (89); G2242 (88); G1764 (86); Altyn Dala (89), which was not previously selected.

Keywords: Durum wheat, gluten quality, gluten index.

Качество зерна является сложным признаком, слагаемым множеством различных показателей: содержание белка и клейковины, фракций белка, амилозы, твердозерность, стекловидность и т.д. Природно-климатические условия яровосеющей зоны Казахстана способствуют формированию высокопротеинового зерна. Важное значение придается сорту и реализации его потенциала в конкретных условиях выращивания. Лимитирующим показателем для яровой твердой пшеницы является качество клейковины, определяемое по стандартам ИСО как глютен-индекс.

Цель данных исследований: 1) дать всестороннюю объективную оценку качества клейковины новых перспективных сортов по показателю глютен-индекс в сравнении со стандартами ГОСТ.

Материал и методы исследований. Объекты исследований: Образцы КСИ, КП, СП-2 и малое размножение яровой твердой пшеницы Карабалыкской СХОС 2017-2018 гг.

Методы исследований: Методы определения качества зерна [1].

Результаты и обсуждение. Натурная масса зерна варьирует в широких пределах от 560 г/л (Г 1846) до 746 г/л (Г 2611) при среднем для всего блока 665 г/л. Ряд генотипов выделяется относительно высоконатурным зерном выше $\geq 700$ г/л.

По стекловидности зерна весь блок характеризуется очень высоким значением 93-98 \%, как и по твердозерности от 74 до 81 ед. SKCS (табл. 1). 
Таблица 1 - Характеристика блока яровой твердой пшеницы (КСИ) по качеству зерна и муки, выращенной Карабалыкской СХОС, ур. 2017 г.

\begin{tabular}{|c|c|c|c|c|c|c|c|c|c|c|}
\hline \multirow[b]{2}{*}{ Каталог } & \multirow[b]{2}{*}{ 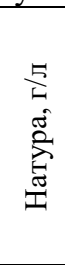 } & \multirow[b]{2}{*}{ 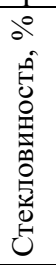 } & \multirow[b]{2}{*}{ 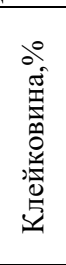 } & \multirow[b]{2}{*}{ 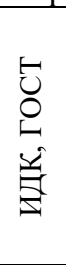 } & \multirow[b]{2}{*}{$\begin{array}{l}\dot{0} \\
\hat{\Xi}\end{array}$} & \multirow[b]{2}{*}{ 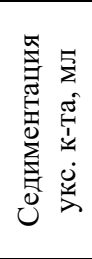 } & \multirow[b]{2}{*}{ 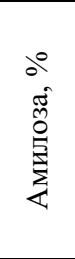 } & \multicolumn{3}{|c|}{ Зерно } \\
\hline & & & & & & & & 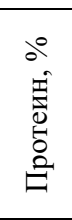 & 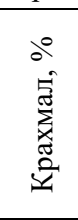 & 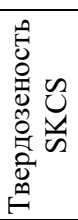 \\
\hline Г 1764 & 595 & 94 & 20,6 & 100 & 274 & 26 & 30,6 & 12,2 & 60,1 & 79 \\
\hline Г1846 & 560 & 97 & 22,8 & 110 & 277 & 25 & 28,9 & 12,8 & 59,1 & 75 \\
\hline$\Gamma 2246$ & 703 & 96 & 24,9 & 115 & 268 & 24 & 31,0 & 12,7 & 61,5 & 76 \\
\hline Г 2267 & 614 & 93 & 24,4 & 110 & 275 & 25 & 29,7 & 13,0 & 59,2 & 79 \\
\hline Г 2345 & 717 & 95 & 29,6 & 120 & 327 & 26 & 27,3 & 14,2 & 60,1 & 74 \\
\hline Г 2363 & 615 & 97 & 23,4 & 120 & 329 & 25 & 25,6 & 13,3 & 59,5 & 79 \\
\hline Г 2409 & 699 & 96 & 29,4 & 120 & 208 & 26 & 29,7 & 14,0 & 59,6 & 80 \\
\hline$\Gamma 2580$ & 681 & 98 & 24,8 & 120 & 166 & 26 & 31,3 & 12,3 & 60,6 & 78 \\
\hline$\Gamma 2589$ & 697 & 95 & 25,4 & 115 & 290 & 24 & 28,1 & 12,5 & 60,4 & 79 \\
\hline$\Gamma 2601$ & 622 & 94 & 22,0 & 120 & 361 & 26 & 30,2 & 12,4 & 60,3 & 74 \\
\hline Г 2607 & 706 & 97 & 28,8 & 120 & 321 & 28 & 27,3 & 13,2 & 60,4 & 74 \\
\hline Г 2611 & 746 & 98 & 30,0 & 120 & 292 & 24 & 29,7 & 13,7 & 60,2 & 78 \\
\hline Г 2638 & 706 & 93 & 29,2 & 120 & 263 & 30 & 23,1 & 14,4 & 59,1 & 76 \\
\hline Г 2640 & 704 & 95 & 30,8 & 120 & 278 & 25 & 25,6 & 14,8 & $\begin{array}{l}58,9 \\
\end{array}$ & 81 \\
\hline Г2654 & 608 & 96 & 22,4 & 115 & 289 & 28 & 24,8 & 11,7 & 60,7 & 75 \\
\hline
\end{tabular}

Содержание протеина в зерне варьировало от 11,7 \% (Г 2654) до 14,8 \% (Г 2640). Уровень 14,0 \% и выше (базовый для высококачественных пшениц) характерен дополнительно для номеров: Г 2638 (14,4 \%); Г 2409 $(14,0 \%)$ и Г $2345(14,2 \%)$.

Содержание клейковины в зерне согласно ГОСТ варьировало для данного блока от 20,6 \% (Г 1764) до 30,8 \% (Г 2640) при среднем 25,9 \%. Основная часть испытанного блока формировало количество клейковины, соответствующее 3-ему классу при заготовке в пределах 23,0-28,0 \%.

При этом по качеству клейковина отнесена к классу «слабая» $(100$ 120 ед. ИДК) за исключением только 1 образца с качеством клейковины класса «филер» (100 ед. ИДК). Класс качества клейковины подтверждается низкими значениями седиментации муки в уксусной кислоте от 24 мм (Г 2246; Г 2589; Г 2611) до 30 мл (Г 2638). При этом другой метод седиментации Зелени (молочная кислота) дал более высокую разрешающую способность в дифференциации генотипов от 36 мл (Г 1764; Г 2654) до 54-57 мл (Г 2638; Г 2640), коррелирующее с $\min$ и max содержанием протеина в зерне $11,7-12,9 \%$ и $14,4-14,8 \%$ соответственно.

Не менее важной составляющей качества зерна твердой пшеницы является состояние крахмального комплекса. Содержание крахмала варьировало в 
незначительных пределах от 58,9 \% (Г 2640 - самый белковый) до 61,5 \% (Г 2246) при среднем 60,0 \% для всего блока. Качество крахмала определяется соотношением амилоза/амилопектин. Изменчивость по содержанию амилозы в муке представлено рядом образцом от 23, 1 \% (Г 2638) до 31,0-31,3 \% (Г 2246; Г 2580) параллельно тенденции увеличения содержания крахмала. К характеристике крахмального комплекса относится и оценка $\alpha$-амилазной активности - «число падения». Значения порядка 160-180 сек позволяет расценивать зерно с высокой амилолитической активностью.

Таких образцов отмечено 2: Г 2580 (166 сек) с тах содержанием амилозы и Г 2409 (208 сек). В целом, блок характеризуется варьированием ЧП от 166 до 361 сек (Г 2601) при среднем 281 сек. Четыре образца отвечают самым высоким требованиям (300 сек>): Г 2601; Г 2363; Г 2345 и Г 2607.

В урожае 2018 г. весь блок конкурсного сортоиспытания представлен высоконатурными образцами 782-830 г/л. Весь блок относительно выравненный и среднее значение более 800 г/л (табл. 2).

Таблища 2 - Характеристика блока КСИ яровой твердой пшеницы Карабалыкской СХОС по качеству зерна, ур. 2018 г.

\begin{tabular}{|c|c|c|c|c|c|}
\hline \multirow{2}{*}{ Показатели } & \multirow{2}{*}{$\min$} & \multirow{2}{*}{$\max$} & \multirow{2}{*}{ cp. } & \multicolumn{2}{|c|}{ Генотипы со значением: } \\
\hline & & & & $\max$ & $\min$ \\
\hline Натура, г/л & 708 & 830 & 802 & $\begin{array}{c}\text { Черноклосая 24, Кара- } \\
\text { балыкская черноколо- } \\
\text { сая, Г2324 }\end{array}$ & $\Gamma 2504$ \\
\hline Протеин, \% & 10,8 & 13,2 & 12,2 & $\begin{array}{c}\text { Г2242, Г2363, Шарифа, } \\
\text { Асангали }\end{array}$ & $\begin{array}{l}\text { Г2408, Г1760, Г2532, } \\
\text { Алтын Дала }\end{array}$ \\
\hline $\begin{array}{l}\text { Твердозерность, } \\
\text { ед. SKCS }\end{array}$ & 47 & 85 & 69 & Г2242, Г2510 & Черноколосая 9 \\
\hline Крахмал, \% & 61,7 & 65,2 & 63,6 & $\begin{array}{c}\Gamma 2408, \text { Г2532, Черноко- } \\
\text { лосая } 9\end{array}$ & $\Gamma 2242$ \\
\hline $\begin{array}{l}\text { Седиментация } \\
\text { Зелени }\end{array}$ & 36 & 52 & 42 & $\begin{array}{c}\text { Шарифа, Г2246, Асан- } \\
\text { гали }\end{array}$ & $\begin{array}{c}\text { Г2409, Г28532, Г1760, } \\
\text { Алтын Дала }\end{array}$ \\
\hline $\begin{array}{l}\text { Содержание } \\
\text { клейковины, \% }\end{array}$ & 21,4 & 30,9 & 25,9 & $\begin{array}{c}\text { Г2363, Черноколосая } 7 \\
\text { и 8, Карабалыкская } \\
\text { черноклосая }\end{array}$ & $\begin{array}{c}\text { Г1704-2, Г2408, Алтын } \\
\text { Дала, Г2510 }\end{array}$ \\
\hline $\begin{array}{l}\text { Качество } \\
\text { клейковины, } \\
\text { ИДК }\end{array}$ & 95 & 115 & 105 & $\begin{array}{c}\text { Г2441, Г2510, Г2363, } \\
\text { Г2246, Г2504, Г2514, } \\
\text { Г1764, Г1704-2, Алтын } \\
\text { Дала, Карабалыкская } \\
\text { черноколосая }\end{array}$ & $\begin{array}{c}\Gamma 2345, \text { Г1846, Черноко- } \\
\text { лосая } 8\end{array}$ \\
\hline $\begin{array}{l}\text { Глютен-индекс } \\
\text { GI }\end{array}$ & 29 & 89 & 67 & $\begin{array}{l}\text { Г2510, Алтын Дала, } \\
\text { Г2242, Г1764, Г2246, } \\
\text { Г1704-2, Г2408, Г1760 }\end{array}$ & $\begin{array}{c}\text { Черноколосая 8, Алтын } \\
\text { Шыгыс, Черноколосая } \\
\text { 7, Черноколосая 9, } \\
\text { Г2345, Г2295 }\end{array}$ \\
\hline
\end{tabular}

Содержание протеина блока КСИ яровой твердой пшеницы в Карабалыке варьирует от 11,2 \% (Г1760, Г2408) до 13,3 \% (Асангали, Шарифа, 184 
Г2441, Г2363, Г2246) при среднем 12,2 \%).

Содержание крахмала варьирует от 61,7 \% (Г2242) до 65,2 \% (Г2408, Г2532, Черноколосая 9). Последний образец с максимальным содержанием крахмала отличается мягкозерность (47 ед. SKCS), тогда когда весь блок твердозерный (69 ед.SKCS - среднее) и самый твердозерный образец Г2242 (85 ед. SKCS).

Седиментация Зелени характеризует набухаемость и осаждение муки в молочной кислоте. Она варьирует в пределах от 36 мл. (класс филер) до 52 мл (ценная). К классу ценная относятся только три номера: Асангали (50 мл); Шарифа (52 мл) и Г2246 (50 мл). Минимальное значение седиментации Зелени отмечено для номеров: Г2408; Г2532; Г1760 и Алтын Дала (36-37 мл).

Качество непосредственно клейковины, отмытой солевым раствором в муке (ИСО) варьировало от 95 ед. ИДК (2 класс) до 115 ед. ИДК (4 класс) при среднем 105 ед. ИДК.

В пределах 2-ого класса качество клейковины отмечено для номеров Г2441, Г2510, Г2363, Г2246, Н2504, Г2514, Г1764, Г17042 и Карабалыкская черноколосая, Алтын Дала. По индексу клейковины (glutenindex, ИСО) выделены эти же образцы (за исключением Г2363 и Карабалыкская черноколосая) и дополнительно к ним Г2242, Г2408, Г2324, Г1760 с высоким glutenIn$\operatorname{dex}(88,83,81$ и 83 соответственно), но не выделяемые по ИДК. Уровень качества клейковины связан с ее количеством, которое варьировало от 21,4 \% (4 класс слабая) до 30,9 \% (2 класс - ценная).

Максимальное значение клейковины отмечено для генотипов Г2363 (30,9 \%); Черноколосая 7 и Черноколосая 8 (30,7-30,6 \%); Карабалыкская черноклосая (29,2 \%). Минимальное значение клейковины отмечено по номерам Г1704-2 и Г2408 (21,4-21,9 \%), что обусловлено низким содержанием протеина, особенно для номера Г2408 (11, \%). Также низкое содержание протеина для сорта Алтын дала и номера Г210 $(11,2-11,5 \%)$ детерминировало и низкое содержание клейковины в муке (22,7-22,8 \%).

В основном для блока характерно количество клейковины в пределах 3-го класса 23,0-28,0 \% клейковины.

Выводы. По всем показателям как наиболее соответствующим требованиям качества выделены генотипы: Г2441, Г2246, Шарифа, Асангали; а также ряд образцов с высоким значением глютен-индекса Г2510 (89); Г2242 (88); Г1764 (86); Алтын Дала (89), на который селекция ранее не велась.

\section{Список литературы}

1 Абугалиева А.И., Зеленский Ю.И., Савин Т.В. Методическая рекомендация «Классификация сортов яровой мягкой пшеницы Международных питомников Казахстанско-Российской сети по показателям качества зерна. - Астана. - 2010. - 61 с. 